(Pôvodná práca - retrospektívna štúdia)

\title{
Oral Carriage of Staphylococcus aureus among Dental Patients in Dependence on Conditions in Oral Cavity
}

\author{
(Original Article - Retrospective Study)
}

\section{Kaiglová A.', Špajdelová J.', Stanko M.2}

'Katedra laboratórnych vyšetrovacích metód v zdravotníctve, Fakulta zdravotníctva a sociálnej práce, Trnavská univerzita, Trnava

2Zubná ambulancia LUXDENT, s.r.o., Nitra

\begin{abstract}
SÚHRN
Úvod a ciel: Staphylococcus aureus je významným oportunistickým patogénom s vel'mi variabilným genómom, takže je zodpovedný za široké spektrum ochorení. Významným miestom výskytu tohto patogénu u zdravých jedincov, vrátane kmeňov rezistentných voči meticilínu, je okrem iných orgánov, akými sú napr. koža, hltan, sliznica nosa apod., aj ústna dutina. Hlavným ciel'om našej štúdie bolo preto zistit', či rôzne podmienky $v$ ústnej dutine, ako parodontitída, fixné a snímatel'né protetické zubné náhrady a stomatologické ochorenia s indikáciou na extrakciu, majú vplyv na mieru kolonizácie ústnej dutiny týmto mikroorganizmom a zároveň stanovit' frekvenciu výskytu meticilín rezistentných kmeňov Staphylococcus aureus u stomatologických pacientov.
\end{abstract}

Metódy: Vyšetrovaný súbor pozostával z 96 pacientov, ktorí v období od júna 2014 do januára 2015 navštívili zubnú ambulanciu LUXDENT, s.r.o., v Nitre. Súbor bol rozdelený do štyroch skupín podl'a podmienok v ústnej dutine - a to do skupiny pacientov: 1. s parodontitídou, 2. so stomatologickými ochoreniami s indikáciou na extrakciu, 3. s fixnými alebo snímatel'nými zubnými náhradami a 4. do kontrolnej skupiny. Pacientom sa sterilným tampónom urobili výtery z nosovej a ústnej dutiny a do 24 hodín sa transportovali do laboratória. V laboratóriu sa vzorky spracovali štandardnými metódami pre izoláciu a identifikáciu Staphylococcus aureus, s následnou konfirmáciou druhu metódou polymerázovej rețazovej reakcie, kde sa amplifikoval špecifický úsek nuc génu o vel'kosti cca 270 bp, charakteristický pre tento druh mikroorganizmu. Meticilín rezistentné kmene Staphylococcus aureus sa identifikovali pomocou diskovej difúznej metódy podla metodiky Európskeho výboru pre testovanie antimikrobiálnej citlivosti [8]. Výsledky: Prítomnost' tohto mikroorganizmu sa zistila v 35 vzorkách (20,2 \%) zo 173 vyšetrených vzoriek (výtery z orálnej a nazálnej dutiny), z toho 31 vzoriek bolo na meticilín senzitívnych $(88,58$ \%) a štyri vzorky boli voči meticilínu rezistentné (11,42 \%). Medzi výskytom mikroorganizmu v nose a ústach bol štatisticky významný rozdiel ( $p$ <,05), s častejším výskytom v nazálnej dutine. Iba u troch z 96 pacientov (3,12 \%) sa dokázala prítomnost' Staphylococcus aureus zároveň v nazálnej aj orálnej dutine. Pri porovnaní skupiny pacientov s fixnými a snímatel'nými protetickými náhradami s ostatnými skupinami bol výskyt mikroorganizmu Staphylococcus aureus v tejto skupine signifikantne vyšší $(p<0,05)$.

Závery: Naše výsledky indikovali, že orálna dutina môže byṫ primárne (bez súčasnej prítomnosti mikroorganizmu $\vee$ nose) kolonizovaná zlatým stafylokokom a podmienky $v$ ústnej dutine, ako napr. fixné a snímatel'né zubné náhrady, môžu mat́ na jej kolonizáciu významný vplyv.

Klíčové slova: Staphylococcus aureus - meticilín rezistentný Staphylococcus aureus - ústna dutina parodontitída - protetické zubné náhrady 


\section{SUMMARY}

Introduction and aim: Staphylococcus aureus is a significant opportunistic pathogen possessing highly variable genome, causing thus wide range of infections. An important location where this pathogen may occur in healthy individuals includes not only organs such as skin, pharynx, nasal mucosa, etc., but also oral cavity. The main objective of our study was to find out whether various oral cavity conditions such as periodontitis, fixed and removable dental prostheses and stomatological diseases with indications for extraction influence the level of oral cavity colonization by the Staphylococcus aureus, as well as to define the frequency of occurence of methicillin-resistant strains of this microorganism in stomatological patients. Methods: The examined collection consisted of 96 patients, who attended dental services LUXDENT, Ltd., in Nitra from June 2014 to January 2015. Patients were divided into the groups studied, i.e., the group of patients with 1. periodontitis, 2. dental diseases with indications for extraction, 3. fixed or removable prosthetic restorations and 4. control group. Microbiological samples were obtained by sterile swabs from oral and nasal cavity of subjects included into study and delivered to the laboratory within $24 \mathrm{~h}$. At the laboratory, samples were processed by standard methods for isolation and identification of Staphylococcus aureus and confirmed by polymerase chain reaction, in which the specific region of nuc gene, characteristic for Staphylococcus aureus was amplified. Methicillin-resistant strains of Staphylococcus aureus were identified using disc difusion method according to the methodology of the European Committee on Antimicrobial Susceptibility Testing [8].

Results: The presence of S. aureus was found in 35 samples (20.2\%) out of 173 examined samples (oral and nasal cavity swabs), while 31 of those samples were methicillin-sensitive (88.58\%) and four of them were methicillin-resistant (11.42\%). There was a statistically important difference between the occurrence of the microorganism in nose and mouth $(p<0,05)$ indicating a more frequent occurrence in the nasal cavity. The presence of the microorganism in both nasal and oral cavities simultaneously was discovered only in three out of 96 patients (3.12\%). When comparing the group of patients with fixed and removable prostheses to other groups, the occurrence of microorganism studied was significantly higher $(p<0,05)$. Conclusions: Our results indicate that the oral cavity may be an important site of Staphylococcus aureus colonisation and the conditions in the oral cavity, e.g., fixed and removable restorations may promote oral carriage of this microorganism.

KEYWORDS: Staphylococcus aureus - methicillin resistant Staphylococcus aureus - oral cavity - parodontitis - dental prostheses

\section{ÚVOd A CIEL' ŠTÚdIE}

Napriek množstvu vedeckých publikácií venovaných potenciálne patogénnemu mikroorganizmu Staphylococus aureus (S. aureus) a koaguláza negatívnym stafylokokom, je dostupných relatívne málo údajov o orálnej dutine ako rezervoári tohto mikroorganizmu. Orálna flóra pozostáva $\mathrm{z}$ viac ako 300 druhov baktérií a množstva nekultivovatel'ných mikroorganizmov, ktoré boli objavené až molekulárnymi biologickými technikami. Zatial' čo dôležitost' stafylokokov ako medicínsky významných patogénov je známa už mnoho rokov, existuje pomerne málo detailných štúdií o distribúcii stafylokokov v orálnej dutine. Je zjavné, že ústna dutina môže byt popri nazálnej dutine dôležitým rezervoárom stafylokokových infekcií - vrátane meticilín rezistentných, ktoré za istých podmienok môžu spôsobit závažné ochorenia organizmu, vrátane infekčnej endokarditídy [11]. Meticilín rezistentné kmene S. aureus
(MRSA), ktoré vykazujú mnohopočetnú rezistenciu voči bežne používaným antibiotikám sú jedným z najvýznamnejších gram-pozitívnych rezistentných patogénov. Okrem nemocničných kmeňov MRSA, spôsobujúcich nozokomiálne ochorenia, sa koncom minulého storočia objavujú u pacientov $\mathrm{v}$ ambulanciách aj tzv. komunitné (community-aquired) kmene, ktoré boli izolované od jedincov s negatívnou históriou pobytu v nemocničnom prostredí. Výsledky mnohých štúdií poukázali na zvyšujúci sa výskyt infekcií spôsobených komunitnými kmeňmi MRSA aj v bežnej populácii $[24,25,26]$.

Informácií o podmienkach v ústnej dutine, ktoré podporujú jej kolonizáciu týmto patogénom, je však málo. Väčšina štúdií, ktorá sledovala možnost' eleminovat' S. aureus z možného rezervoára infekcií sa zaoberala skôr prítomnostou tohto mikroorganizmu v nazálnej dutine, zatial' čo orálna dutina bola z tohto pohl'adu dlhodobo prehliadaná [16]. Ciel'om našej štúdie bolo preto zistit', či rôzne podmienky 


\section{METÓDY}

V spolupráci so stomatológom boli pacienti, ktorí boli oboznámení o štúdii a súhlasili s odberom vzoriek, zaradení do štyroch sledovaných skupín, a to do skupiny pacientov: 1 . s parodontitídou, 2 . so stomatologickými ochoreniami s indikáciou na extrakciu, 3. s fixnými alebo snímatel'nými zubnými náhradami a 4. do kontrolnej skupiny. Pacientom sa sterilným tampónom, ktorý bol súčastou odberovej súpravy Amies s agarovým gélovým transportným médiom bez aktívneho uhlia (fy Copan,Taliansko), urobili výtery z nosovej a ústnej dutiny a do 24 hod. sa transportovali do laboratória. Na zaradenie pacientov do prvej skupiny sa najskôr zistili hodnoty CPI indexu, na základe ktorých sa diagnostikoval stupeň poškodenia parodontu. Pacientom s parodontitídou sa potom odobrala vzorka pomocou papierových čapov, ktoré sa vložili do parodontálnych chobotov a následne do transportného média. Okrem papierových čapov sa do transportného média odobrala čast' zubného kameňa. V skupine so stomatologickými ochoreniami s indikáciou na extrakciu sa pri extrakcii radixov do transportného média odobrali extrahované radixy zubov. U pacientov so snímatel'nými náhradami bol ster robený priamo z miesta, kde protéza nasadá na sliznicu dutiny ústnej. Pri skupine s fixnými protetickými náhradami sa urobil ster vatovým tampónom v oblasti krčku zuba na vestibulárnej plôške. Kontrolnej skupine (pacienti so sanovaným chrupom, bez prítomnosti parodontitídy a protetických náhrad) bol sterilným tampónom odobraný ster zo supragingiválnej oblasti. V laboratóriu sa vzorky spracovali štandardnými metódami pre izoláciu a identifikáciu S. aureus. Odobratý biologický materiál sa z tampónu odberovej súpravy naniesol na krvný agar a na selektívno-diagnostickú pôdu - manitolový slaný agar (MSA) fy MkB Test, a.s., Slovensko, ktorý sa inkuboval 48 hodín pri teplote $37^{\circ} \mathrm{C}$.

Manitol-pozitívne kolónie boli d'alej analyzované farbením podl'a Grama, katalázovým testom na dôkaz produkcie enzýmu katalázy a rýchlym aglutinačným testom PROLEX ${ }^{\text {TM }}$ STAPH LATEX KIT, fy Pro-Lab Diagnostics, Vel'ká Británia, na prítomnost' proteínu A a viazanej koagulázy (,clumping faktoru“). PROLEX ${ }^{\text {TM }}$ STAPH LATEX KIT využíva latexové častice, senzibilizované fibrinogénom a IgG. Ak sa na bunkovej stene testovaných baktérií nachádza viazaná koaguláza (clumping factor) a/alebo proteín A, po ich zmiešaní s reagentom pozorujeme viditel'nú silnú aglutináciu latexových častíc, ktorá nastáva do 20 sekúnd po zmiešaní kolónií s reagentom. Kontrola testu sa uskutočňuje pomocou negatívneho kontrolného latexového reagentu, ktorý obsahuje latexové častice bez senzibilizácie.

Konfirmácia druhu S. aureus sa potom vykonala metódou polymerázovej retazovej reakcie (PCR), pričom sa zistovala prítomnost' špecifického fragmentu (cca 279bp) nuc génu, kódujúceho termostabilnú nukleázu tohto mikroorganizmu. Amplifikácii špecifického fragmentu nuc génu predchádzala izolácia DNA. Amplifikovaný úsek sa následne vizualizoval elektroforeticky za použitia agarózového gélu (obr. 1).

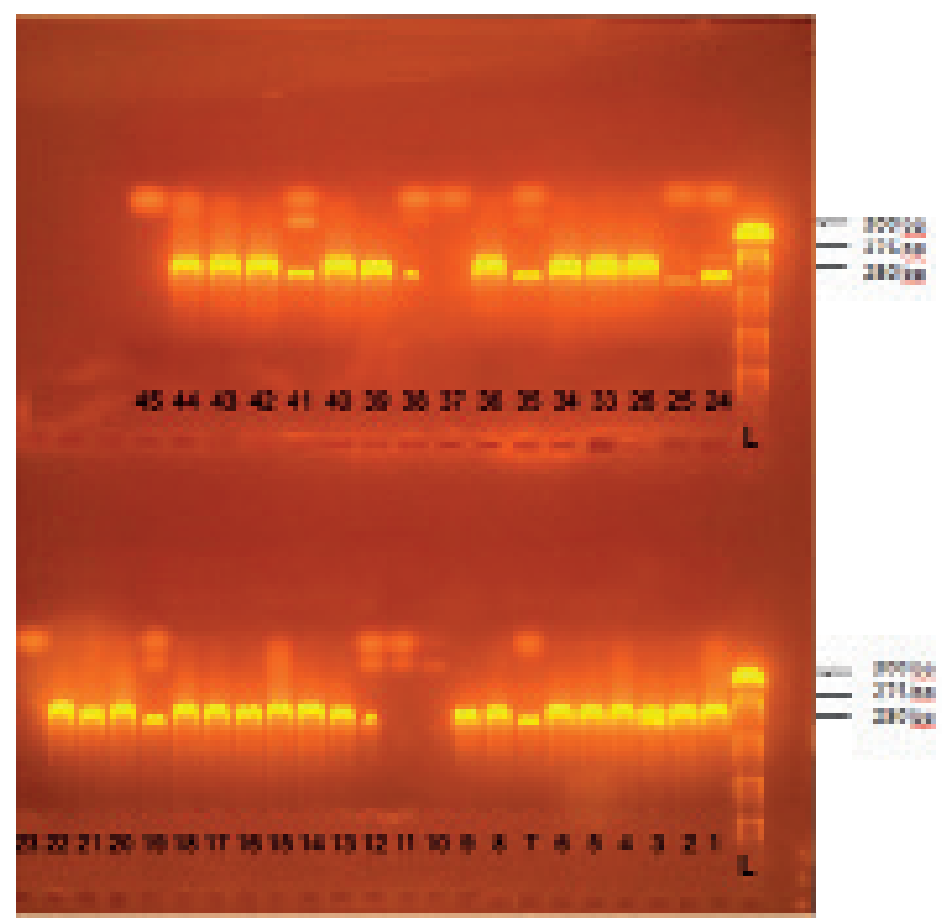

Obr. 1 Príklad gélovej elektroforézy amplifikovaného PCR produktu - špecifického úseku nuc génu $S$. aureus

L -DNA ladder, 44 - pozitívna kontrola, 45 - negatívna kontrola, 10, 11, 23, 25, 37 - negatívne vzorky, ostatné jamky - pozitívne vzorky

\section{Izolácia DNA}

Bakteriálna kultúra bola počas 24 hodín pri $37^{\circ} \mathrm{C}$ rozmnožená v Muellerovom-Hintonovom bujóne a následne resuspendovaná vo fyziologickom roztoku tak, aby výsledná hustota suspenzie bola cca $1 \times 10^{8}$ baktérií/ml. Suspenzia baktérii $(500 \mu \mathrm{l})$ sa centrifugovala pri $6000 \times$ g počas troch minút. Po odstránení supernatantu boli usadené pelety následne resuspendované v $500 \mu \mathrm{l}$ TE pufri (Tris-EDTA: $10 \mathrm{mM}$ trisHCL, $1 \mathrm{mM}$ EDTA - pH 8) a inkubované počas troch minút pri izbovej teplote. Po centrifugácii pri 6000× g 
počas troch minút a odstránení supernatantu boli pelety resuspendované v $250 \mu \mathrm{l}$ PCR vody a vystavené teplote $100{ }^{\circ} \mathrm{C}$ počas $10 \mathrm{~min}$. $\mathrm{v}$ termobloku. Po ochladení na izbovú teplotu bola bakteriálna suspenzia centrifugovaná pri 13000 krát g počas 5 min., čím bola získaná uvol'nená DNA obsiahnutá v supernatante.

\section{PCR amplifikácia}

Amplifikácia špecifického úseku nuc génu S. aureus o vel'kosti cca 270 bp sa uskutočnila v termocykleri T3000 Biometra, pričom boli použité primery podl'a Brakstadta a kol. [3]. Ako master mix bol použitý komerčne dostupný Go Taq Green Master Mix (výrobca: Promega Corporation, USA).

Použitý program PCR bol nasledovný: 1. úvodná denaturácia - 4 min. $\left(94^{\circ} \mathrm{C}\right) ; 2$. denaturácia DNA 45 sekúnd $\left(94^{\circ} \mathrm{C}\right) ; 3$. anelácia -45 sekúnd $\left(50^{\circ} \mathrm{C}\right) ; 4$. polymerizácia DNA - 60 sekúnd $\left(72^{\circ} \mathrm{C}\right) ; 5$. záverečná polymerizácia DNA $-2 \mathrm{~min}$. $\left(72{ }^{\circ} \mathrm{C}\right)$. Kroky 2, 3 a 4 sa opakovali tridsat́krát.

\section{Vizualizácia amplifikovaných vzoriek}

Amplifikované vzorky sa d'alej analyzovali elektroforézou. Použil sa dvojpercentný agarózový gél na separáciu fragmentov. Na označenie DNA sa použila GelRed farbička (výrobca: Biotium Inc., USA).

\section{Diskový difúzny test}

Izoláty S. aureus sa d'alej testovali diskovou difúznou metódou na citlivost' k cefoxitínu podla metodi- ky Európskeho výboru pre testovanie antimikrobiálnej citlivosti [8]. Podl'a doporučení tejto organizácie, ako aj Inštitútu pre klinické a laboratórne štandardy [5] je diskový difúzny test s použitím diskov s obsahom $30 \mu \mathrm{g}$ cefoxitínu odporúčanou metódou na stanovenie meticilín rezistentných kmeňov S. aureus (MRSA). Za rezistentné sme považovali kmene so zónou inhibície menšou ako $22 \mathrm{~mm}$, za citlivé so zónou inhibície väčšou ako $22 \mathrm{~mm}$. Všetci pacienti zaradení do štúdie vyplnili dotazník, na základe ktorého sme mohli zistit prípadnú predchádzajúcu históriu hospitalizácie.

\section{VÝSLEDKY}

V tejto štúdii bolo celkovo vyšetrených 96 pacientov, ktorí boli zaradený v spolupráci so zubným lekárom do štyroch sledovaných skupín, a to do skupiny pacientov s parodontitídou, zubnými náhradami, stomatologickými ochoreniami s indikáciou na extrakciu a do kontrolnej skupiny. $\mathrm{Z}$ celkového počtu vyšetrených vzoriek bolo 77 výterov z nosa a 96 výterov z úst. Na štúdii sa zúčastnilo 63 žien a $33 \mathrm{mu}$ žov. Najstarším pacientom bola 88ročná žena a najmladším pacientom bol 32ročný muž. Štatistická analýza (Mannov-Whitneyho U test a Pearsonov $\chi^{2}$ test) nedokázala signifikantný vplyv veku ani pohlavia na výskyt mikroorganizmu S. aureus v ústnej dutine.

Prítomnost' S. aureus sa zistila v 35 vzorkách z celkového počtu 173 vyšetrených vzoriek, z toho 77 vzo-

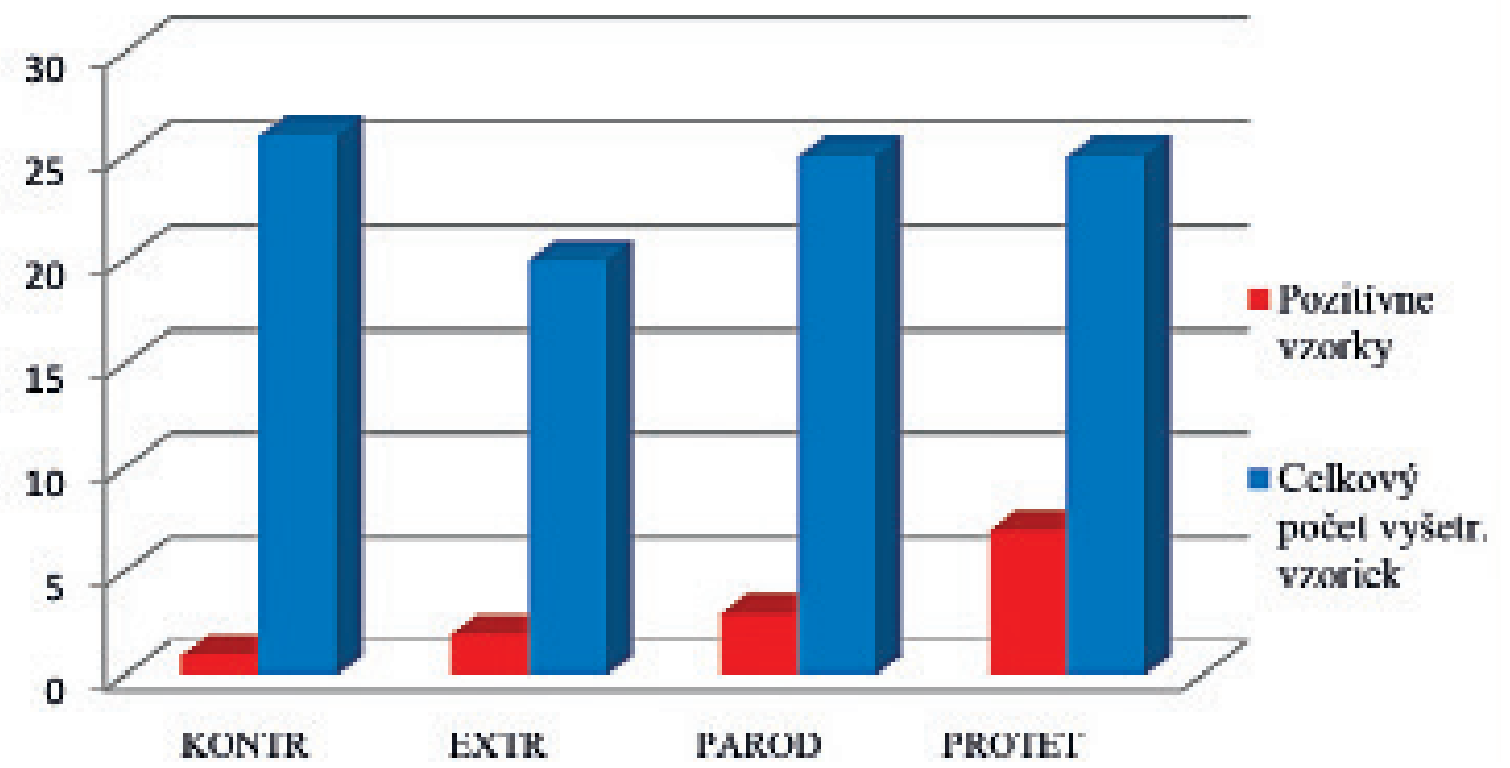

Graf 1 Výskyt $S$. aureus v dutine ústnej v jednotlivých sledovaných skupinách

KONTR kontrolná skupina, EXTR skupina s indikáciami na extrakciu, PAROD skupina s parodontitídou, PROTET skupina s protet. náhradami 
Kaiglová A., Špajdelová J., Stanko M., Dubajová E.

ČESKÁ STOMATOLOGIE ročník 116, 2016,1 , s. $12-19$

Tab.1 Porovnanie výskytu SAU vs SAN v jednotlivých skupinách

\begin{tabular}{|l|l|l|l|}
\hline & SAU & SAN & SAU vs SAN (pomer) \\
\hline Kontrolná skupina (40) & $10 \%(2)$ & $25 \%(5)$ & 0,4 \\
\hline Skupina s parodontitídou (47) & $12 \%(3)$ & $32 \%(7)$ & 0,38 \\
\hline Skupina s protet. náhradami (47) & $28 \%(7)$ & $18 \%(4)$ & 1,54 \\
\hline Skup. s indikáciami na extrakciu (39) & $4 \%(1)$ & $31 \%(4)$ & 0,13 \\
\hline
\end{tabular}

SAU \% izolátov $S$, aureus v ústach (počet), SAN \% izolátov $S$. aureus v nose (počet)

riek pochádzalo z nosa a 96 vzoriek z úst pacientov. Celkový výskyt zlatého stafylokoka v sledovanom súbore bol 20,2\%. Z 35 vzoriek s dokázanou prítomnostou $S$. aureus pochádzalo 22 vzoriek z nosa a 13 vzoriek z dutiny ústnej. V prípade troch pacientov $(3,12 \%)$ sa dokázala prítomnost' toho mikroorganizmu zároveň v nose aj v dutine ústnej.

Pri porovnaní výskytu $S$. aureus $v$ ústach a v nose bol vyšší výskyt tejto baktérie v nose (22 zo 77) ako $\mathrm{v}$ ústach $\left(13 \mathrm{z}\right.$ 96). $\chi^{2}$ testom sme zistili, že medzi výskytom $S$. aureus $v$ nose a ústach bol štatisticky významný rozdiel $(\mathrm{p}<0,05)$.

Z grafu 1 vidiet', že najväčší podiel pozitívnych vzoriek je v skupine pacientov s protetickými náhradami. Avšak vzhl'adom na nízky počet pozitívnych vzoriek sme pri použití Fisherovho testu nepotvrdili štatisticky významný rozdiel medzi skupinami $(p=0,09)$. Preto sme $v$ d'alšom skúmaní použili Pearsonov $\chi^{2}$ test a porovnali skupiny s protetickými náhradami voči ostatným skupinám (graf 2), pričom sme zistili medzi skupinou pacientov s protetickými náhradami s ostatnými skupinami štatisticky významný rozdiel $\left(x^{2}=4,48 ; p<0,05\right)$. Výskyt $S$. aureus bol v tejto skupine približne štyrikrát častejší ( $\mathrm{OR}=$ $4,21 ; C I=95 \%)$.

Taktiež pri porovnávaní pomeru medzi prítomnostou mikroorganizmu S. aureus v ústach a v nose v skupine pacientov s protetickými zubnými náhradami bol tento pomer obrátený ako v kontrolnej skupine a skupine s parodontitídou a extrakciami (tab. 1).

Z celkového počtu 35 izolovaných vzoriek S. aureus sme zistili v štyroch $(11,42 \%)$ prípadoch kmeň MRSA. Z toho ani jeden pacient nemal MRSA kmeň aj v ústach aj v nose.

\section{DISKUSIA}

S. aureus je významným oportunistickým patogénom s vel'mi variabilným genómom, takže je zodpovedný za široké spektrum infekcií. Významným miestom výskytu tohto patogénu u zdravých jedin-

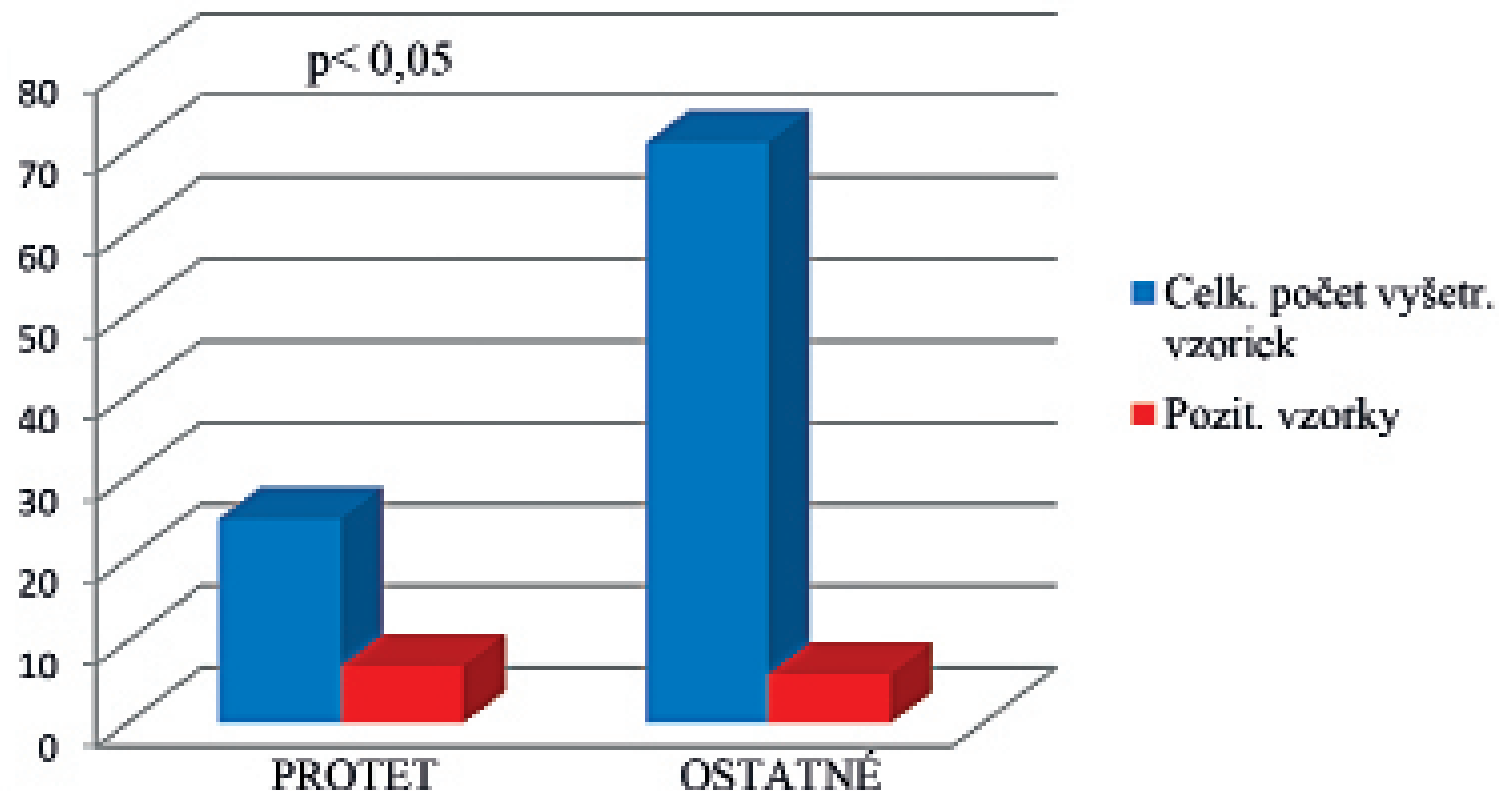

Graf 2 Výskyt $S$. aureus v dutine ústnej - porovnanie skupiny s protetickými náhradami s ostatnými skupinami PROTET skupina s protetickými náhradami, OSTATNÉ - súbor pozostávajúci z pacientov ostatných vyšetrovaných skupín 
cov, vrátane meticilín rezistentných kmeňov, je okrem iných orgánov, ako je koža, hltan, sliznica nosa apod., aj dutina ústna $[2,4,16]$. Navyše, ako naznačujú d'alšie štúdie, S. aureus sa môže pravdepodobne z ústnej dutiny diseminovat' aj do iných častí tela a spôsobit tu závažné infekcie [11, 21].

Čo sa týka zisteného percenta pozitívnych nálezov v nosovej dutine, naše výsledky sú podobné tým, ktoré zistili Mehraj a kol. v štúdii náhodne vybraných obyvatel'ov zo severného Nemecka. V tejto štúdii sa vyšetrili nosové výtery od 389 participantov kultivačne a pomocou PCR, pričom S. aureus bol izolovaný v osemdesiatich piatich vzorkách - t.j. 21, 9 \% z celkového počtu participantov [15]. Podobne autori Fomda a kol. izolovali S. aureus z nosovej dutiny u 29,7 \% zdravých jedincov vo vybraných geografických regiónoch v Indii [9]. Mechanizmus vedúci k osídleniu nazálnej dutiny týmto mikroorganizmom je multifaktoriálny a môže byt' ovplyvnený rôznymi okolnostami. S. aureus môže kolonizovat' aj ústnu dutinu, ale informácií o podmienkach, ktoré podporujú jej kolonizáciu týmto mikroorganizmom je menej. Väčšina štúdií, ktorá sledovala možnost' eliminovat' S. aureus z možného rezervoára infekcií sa zaoberala skôr prítomnostou tohto mikroorganizmu v nazálnej dutine [1, 12], zatial' čo orálna dutina bola $\mathrm{z}$ tohto pohl'adu dlhodobo prehliadaná. Práca Nilssona a Rippu však poukazuje na fakt, že S. aureus môže kolonizovat' ústnu dutinu a orofarynx aj bez súčasnej prítomnosti v nazálnej dutine [19], ako je to napokon zrejmé aj z našich pozorovaní.

V rozsiahlej štúdii, pozostávajúcej z testovania 11312 vzoriek v mikrobiologickom laboratóriu v Glasgowe, bol S. aureus izolovaný v 1312 vzorkách pacientov so suspektnými orálnymi a periorálnymi ochoreniami, čo bolo 18 \% z celkového počtu vzoriek [16]. Toto je porovnatel'né s našimi výsledkami $(13,55 \%)$, aj ked' náš súbor pacientov bol ovel'a menší a zahŕňal aj zdravých jedincov, ktorí navštívili zubnú ambulanciu v rámci prevencie a boli zaradení do kontrolnej skupiny. V skupine pacientov s protetickými náhradami sme izolovali S. aureus z ústnej dutiny vo väčšom počte prípadov ako v nose (tab. 1), čo naznačuje, že prítomnost' $S$. aureus $\mathrm{v}$ ústach by mohla primárne súvisiet' s podmienkami v ústnej dutine. Podobne, Passariello a kol. zistili v skupine pacientov s protetickými náhradami a ochoreniami periodontu významne vyšší počet izolátov $S$. aureus v ústnej dutine než v nose $(39,3 \%$ vs. $14,3 \%, p<0,01)$, $\mathrm{v}$ porovnaní s kontrolou [20]. Na rozdiel od tejto štúdie, kde boli zaznamenané signifikantné rozdiely aj v prítomnosti S. aureus v ústnej dutine medzi kontrolou a skupinou pacientov s fixnými a snímatel'nými protetickými náhradami, v našej štúdii tento rozdiel síce bol zaznamenaný, ale nebol na hladine významnosti (graf 1). Preto sme porovnali skupiny s protetickými náhradami so zlúčeným súborom z ostatných skupín (kontrolná skupina, skupina s parodontitídou, skupina s indikáciami na extrakciu) a zistili sme štatisticky významný rozdiel $(\mathrm{p}<0,05)$ - výskyt S. aureus bol v skupine s protetickými náhradami približne štyrikrát častejší ( $\mathrm{OR}=4,21 ; \mathrm{CI}=95 \%)$ ako $\mathrm{v}$ porovnávanom súbore (graf 2).

Aby S. aureus mohol kolonizovat' ústnu dutinu, vyvinul množstvo stratégií, ako napr. uvol'ňovanie extracelulárnych enzýmov alebo formovanie biofilmu. Tento patogén má schopnost' tvorit mnohobunkové spoločenstvá, ktoré rastú ponorené do extracelulárnej matrice - biofilmu, pozostávajúceho z exopolysacharidov, proteínov, nukleových kyselín a lipidov, ktoré chránia mikroorganizmus pred imunitným systémom hostitel'a. Heo a kol. dokázali, že niektoré proteíny v l'udských slinách (imunoglobulín A a G, lyzozým C, mucín 7), ktoré sa podielajú na imunitnej odpovedi hostitel'ského organizmu, sa selektívne viažu na povrch S. aureus [10]. Toto „zosietovanie“ mikroorganizmov s proteínmi môže spôsobit' aglutináciu a následné odstránenie patogénov z ústnej dutiny napr. ich prehltnutím. Je zaujímavé, že kmene S. aureus formujúce biofilm adherujú k týmto proteínom v menšej miere ako planktonické formy. Autori práce sa zmieňujú o možnej asociácii medzi dysfunkciami, týkajúcimi sa tvorby slín, tvorbou biofilmu a kolonizáciou ústnej dutiny S. aureus. Podobne, Kukita a kol. zistili, že S. aureus sa viaže na glykoproteín prítomný v slinách - gp 340, ktorý podporuje bakteriálnu adhéziu na zuby a sliznicu [13]. Schopnost' adhézie je dôležitým faktorom bakteriálnej patogenity. S. aureus vytvára biofilm nielen na hostitel'ských tkanivách, ale aj na materiáloch využívaných pre výrobu protetických náhrad. Merghni a kol. sledovali schopnost' tohto mikrooorganizmu vytvárat' biofilm na bežne používaných dentálnych živiciach Bis-GMA a PMMA a zistili, že 90 \% kmeňov $S$. aureus izolovaného $z$ ústnej dutiny pacientov zubnej ambulancie bolo biofilm-pozitívnych a malo schopnost' tvorit' biofilm na oboch testovaných povrchoch [17]. Práve táto pozoruhodná schopnost adhézie S. aureus na materiály používané pri výrobe protetických náhrad môže byt príčinou aj nami pozorovaného častejšieho výskytu tohto patogénu v skupine pacientov s protetickými náhradami. Ked'že prítomnost' baktérii je kumulovaná v plaku, usadzujúcom sa na zubných náhradách, správna starostlivost' a hygiena dutiny ústnej u týchto pacientov je mimoriadne dôležitá. V štúdii autorov Shetty a kol. sa potvrdzuje, že inštruovanie pacienta o spôsobe udržania hygieny zubných protéz 
ČESKÁ STOMATOLOGIE ročník 116, 2016, s. $12-19$

predchádza ochoreniam parodontu, zubným kazom a zápalovým zmenám na sliznici [23].

Závažné infekcie môžu spôsobit' predovšetkým tzv. meticilín rezistentné kmene S. aureus (MRSA), pre liečbu ktorých možno použit' len obmedzený výber antibiotík. MRSA je okrem oxacilínu, meticilínu a $\beta$-laktámových antibiotík, vrátane cefalosporínov a karbapenémov, často nositel'om mnohopočetnej rezistencie aj na iné bežne používané antibiotiká, ako je erytromycín, klindamycín a tetracyklín. Od roku 1996 sa objavujú správy o zníženej citlivosti MRSA voči vankomycínu. Mechanizmus rezistencie k ß-laktámovým antibiotikám je sprostredkovaný génom mecA, ktorý kóduje PBP-2a (penicillin-binding protein 2a), a je začlenený do chromozómov meticilín citlivého kmeňa S. aureus. Beta-laktámové antibiotiká sa viažu na PBP (t.j. enzým transpeptidázu) a zabraňujú transpeptidácii disacharidových polymérov $\mathrm{N}$-acetylmuramovej kyseliny a N-acetylglukózamínu, čím inhibujú tvorbu bunkovej steny. PBP-2a vykazuje - na rozdiel od PBP v meticilín citlivých kmeňoch nízku afinitu k meticilínu a nezabraňuje formovaniu bunkovej steny baktérie. Pharma-report z roku 2012 tvrdí, že $S$. aureus je jednou z piatich najčastejšie sa vyskytujúcich príčin vzniku nozokomiálnych ochorení. V USA sa každoročne nakazí približne 500000 pacientov [22]. Za distribúciu v populácii vd'ačí MRSA rýchlej klonálnej expanzívnosti existujúcich kmeňov, ako aj schopnosti včlenit MRSA stafylokokovú chromozómovú kazetu do genómu citlivých kmeňov, čím môžu neustále obnovovat' svoj genóm. Takto vzniklo na svete množstvo kmeňov, ktoré sa naučili vyhnút liečbe antibiotikami. Okrem nemocničných kmeňov, spôsobujúcich nozokomiálne ochorenia, sa koncom minulého storočia objavujú u pacientov v ambulanciách aj tzv. komunitné (community-aquired) kmene, ktoré boli izolované od jedincov s negatívnou históriou pobytu $\mathrm{v}$ nemocničnom prostredí alebo inom liečebnom zariadení. Množstvo štúdií dokumentuje, že meticilín-rezistentný S. aureus, ktorý je v posledných rokoch pod selekčným tlakom antibiotík, získal rozhodujúcu schopnost infikovat l'udí aj mimo nemocnice $[6,7,24,26]$. Za rizikovú skupinu l'udí, čo sa týka výskytu komunitných kmeňov MRSA, sa považujú uživatelia injekčných drog, homosexuálna komunita, väzni apod., ale Moran a kol. referovali o zvyšujúcom sa výskyte infekcií spôsobených komunitnými kmeňmi MRSA aj v bežnej populácii [18]. V našej štúdii, kde sme sa zaoberali izolovaním baktérie S. aureus od pacientov zubnej ambulancie, nás zaujímala aj frekvencia výskytu komunitných kmeňov MRSA v tomto súbore. Všetci pacienti, zaradení do štúdie, vyplnili dotazník, na základe ktorého sme mohli vyradit pacientov s prípadnou predchádzajú- cou históriu hospitalizácie alebo pobytu v liečebnom zariadení. Z 35 izolovaných vzoriek S. aureus sme zistili v štyroch prípadoch kmeň MRSA, čo predstavovalo $11,42 \%$. Z toho ani jeden pacient nemal kmeň MRSA zároveň v ústach aj v nose. Napriek tomu, že náš súbor sledovaných pacientov bol pomerne malý ( $\mathrm{n}=$ 96), aj McCormack a kol. v ovel'a rozsiahlejšom súbore referoval o 10\% výskyte MRSA kmeňov, z celkového počtu 1782 sledovaných pacientov s dentálnymi problémami [16]. Orálne nosičstvo MRSA kmeňov môže znamenat' riziko pre infikovanie iných častí organizmu, ale aj možnost' infikovat' d'alších pacientov alebo zdravotníckych pracovníkov. V odbornej literatúre sú zaznamenané minimálne dva prípady prenosu MRSA od zubných lekárov na pacientov [14], preto preventívne opatrenia, ktoré zabránia šíreniu infekcie medzi pacientmi v zubnej ambulancii nadobúdajú mimoriadny význam.

\section{ZÁVER}

Údaje prezentované v tejto štúdii naznačujú, že popri tzv. nosovom nosičstve stafylokokov rezervoárom zlatého stafylokoka môže byt' aj ústna dutina a prítomnost' fixných alebo snímatel'ných protetických náhrad môže významne zvýšit mieru kolonizácie orálnej dutiny týmto mikroorganizmom. Pacienti so zubnými náhradami by preto mali viac dbat́ nielen o dentálnu hygienu dutiny ústnej, ale aj svojej protetickej náhrady. Kl'účom k predchádzaniu vzniku širokého spektra možných infekcií u takýchto pacientov by mohli byt pravidelné preventívne prehliadky u stomatológa s následnou terapiou a taktiež inštruktáž a ošetrenie dentálnou hygieničkou. V našej štúdii sme nedokázali na hladine významnosti vplyv parodontitídy a závažných stomatologických ochorení s indikáciou na extrakciu na osídlenie ústnej dutiny zlatým stafylokokom, aj ked' pokračovanie štúdie s väčším počtom parcipitantov by mohlo vniest' svetlo do tejto problematiky. V sledovanom súbore pacientov sme odhalili aj štyroch nosičov kmeňov MRSA bez predchádzajúcej histórie hospitalizácie v nemocnici. Pretože je známe, že komunitné kmene MRSA majú dvojnásobnú rýchlost šírenia oproti nemocničným kmeňom, preventívne opatrenia, ktoré zabránia šíreniu infekcie medzi pacientmi v zubnej ambulancii nadobúdajú mimoriadny význam.

\section{LITERATÚRA}

1. Ammerlaan, H. S., Kluytmans, J. A., Wertheim, H. F., Nouwen, J. L., Bonten, M. J.: Eradication of methicillin-resistant Staphylococcus aureus carriage: a systematic review. Clin. Infect. Dis., roč. 48, 2009, č. 7, s. 922-930. 
2. Blomqvist, S., Leonhardt, A., Arirachakaran, P., Carlen, A., Dahlén, G.: Phenotype, genotype, and antibiotic susceptibility of Swedish and Thai oral isolates of Staphylococcus aureus. J. Oral Microbiol. [online]. 2015, 7 [cit. 2015-08-15] Dostupný z WWW: http://www.ncbi.nlm.nih.gov/pmc/articles/ PMC4409631/.

3. Brakstad, G. O., Aasbakk, K., Maeland, A. J.: Detection of Staphylococcus aureus by polymerase chain reaction amplification of the nuc gene. J. Clin. Microbiol., roč. 30, 1992, č. 7, s. 1654-1660.

4. Buonavoglia, A., Latronico, F., Greco, M. F., D‘Abramo, M., Marinaro, M., Mangini, F., Corrente, M.: Methicillin-resistant staphylococci carriage in the oral cavity: a study conducted in Bari (Italy). Oral Dis. [online], roč. 16, 2010, č. 5, s. 465-468 [cit. 2015-08-15]. Dostupný z WWW: http://www.ncbi.nlm.nih.gov/ pubmed/20233317.

5. Clinical and Laboratory Standards Institute: NCCLS Performance standards for Antimicrobial disc diffusion tests; Approved standards. 9th ed. CLSI Document M2-M9. Wayne, P. Clinical and Laboratory Standards Institute; 2006.

6. Nozaki, C., Masaki, T., Kim, S. J., Cruz, R. S., Bermido, C. M., Kim, K. Y., Park, C.: Comparative prevalence of community-acquired-methicillin-resistant Staphyloccocus aureus (CA-MRSA) among Students of Centro Escolar University (Philippines), Kumamoto Health Science University (Japan) and Daegu Health College (Korea). Biomed. Res. [online], roč. 26, 2015, s. 259, cit. 2015-08-15]. Dostupný z WWW: http://www.biomedres.info/ yahoo site admin/assets/docs/259-265.64225011.pdf.

7. Di Giacobbe, A., Pecetta, S., Virga, A., Scazzocchio, F., Aquilanti, L., lebba, V., Passariello, C.: Diffusion of meticillin-resistant Staphylococcus aureus USA300 strains in central Italy. Int J. Antimicrob. Agents, roč. 37, 2010, č.4, s. 49-50.

8. European Committee on Antibacteral Susceptibility Testing: EUCAST: AST of bacteria. [on line]. 2014 [cit. 201504-01]. Dostupný z WWW: http://www.eucast.org/ast_of bacteria/.

9. Fomda, A. B. A., Thokar, M. A, Khan, A., Bhat, J. A., Zahoor, D., Bashir, G., Majid, A., Ray, P.: Nasal carriage of methicilin-resistant Staphylococcus aureus among healthy population of Kashmir. Indian J. Med. Microbiol., roč. 21, 2014, č. 13, s. 39-43.

10. Heo, S. M., Choi, K. S., Kazim, L. A., Reddy, M. S, Haase, E. M., Scannapieco, F. A., Ruhl, S.: Host defense proteins derived from human saliva bind to Staphylococcus aureus. Infect. Immun., roč. 81, 2013, č. 4, s. 1364-1373.

11. Kasmi, G., Refatllari, E., Dumani, S., Refatllari, A.: Early infective endocarditis due to Staphylococcus aureus following dental procedures. Clin. Lab., roč. 60, 2014, č. 11, s. 1933-1936.

12. Kaur, D. C., Narayan, P. A.: Mupirocin resistance in nasal carriage of Staphylococcus aureus among healthcare workers of a tertiary care rural hospital. Indian J. Crit. Care Med., roč. 18, 2014, č. 11, s. 716-721.

13. Kukita, K., Kawada-Matsuo, M., Oho, T., Nagatomo, M., Oogai, Y., Hashimoto, M., Suda, Y., Tanaka, T., Komatsuzawa, H.: Staphylococcus aureus SasA is responsible for binding to the salivary agglutinin gp 340, derived from human saliva. Infect. Immun., roč. 81, 2013, č. 14, s. 1870-1879.

14. Martin, M. V., Hardy, P.: Two cases of oral infection by methicillin-resistant Staphylococcus aureus. Brit. Dent. J., roč. 170, 1991, č. 2, s. 63-64.

15. Mehraj, J., Akmatov, M. K., Strompl, J., Gatzemeier, A., Layer, F., Werner, G., Pieper, D. H., Medina, E., Witte, W., Pessler,
F., Krause, G.: Methicillin-sensitive and methicillin-resistant Staphylococcus aureus nasal carriage in a random sample of non-hospitalized adult population in northern Germany. PLoS One, roč. 9, 2014, č. 9, s. 24-29.

16. McCormack, M. G., Smith, A. J., Akram, A. N., Jackson, M., Robertson, D., Edwards, G.: Staphylococcus aureus and the oral cavity: An overlooked source of carriage and infection? Am. J. Infect. Control, roč. 43, 2015, č. 1, s. 35-37.

17. Merghni, A., Nejma, B. M., Hentati, H., Mahjoub, A., Mastouri, M.: Adhesive properties and extracellular enzymatic activity of Staphylococcus aureus strains isolated from oral cavity. Microb. Pathog., roč. 73, 2014, s. 7-12.

18. Moran, G. J., Krishnadasan, A., Gorwitz, R. J., Fosheim, G. E., Mcdougal, L. K., Carey, R. B., Talan, D. A.: Methicillin-resistant $S$. aureus infections among patients in the emergency department. N. Engl. J. Med., roč. 355, 2006, s. 666-674.

19. Nilsson, P., Ripa, T.: Staphylococcus aureus throat colonization is more frequent than colonization in the anterior nares. J. Clin. Microbiol., roč. 44, 2006, č. 9, s. 3334-3339.

20.Passariello, C., Puttini, M., lebba, V., Pera, P., Gigola, P.: Influence of oral conditions on colonization by highly toxigenic Staphylococcus aureus strains. Oral Dis., roč. 18, 2012, č. 4, s. 402-409.

21. Petti, S., Polimeni, A.: Risk of methicillin-resistant Staphylococcus aureus transmision in the dental healthcare setting: a narrative review. Infect. Control. Hosp. Epidemiol., roč. 32, 2011, č. 11, s. 1109-1115.

22. Pharma-reports: Klinicky významné bakterie. 1. vyd., Praha, Triton, 2012, 128 s. ISBN 978-80 -7387-588-6.

23. Shetty, S. M., Shenoy, P. R., George, T. V.: Role of self care practices and denture maintenance in oral health, J. Orofac. Res., roč. 4, 2014, č. 1, s. 7-11.

24. Shetty, V., Trumbull, K., Hegde, A., Shenoy, V., Prabhu, R. K. S., Palavecino, E., Shetty, A. K.: Prevalence of community-acquired methicillin-resistant Staphylococcus aureus nasal colonization among children. J. Clin. Diagn. Res. [online], roč. 8, 2014, č. 12, s. 12-15 [cit. 2015-08-02]. Dostupný z WWW: http://www. ncbi.nlm.nih.gov/pubmed/25653946.

25. Kim, S. J., Park, C.: Panton-valentine leukocidin and staphylococcal cassette chromosome (SSCmec) from CA-MRSA (Community-Acquired Methicillin Resistant Staphylococcus aureus). Biomed. Res. [online], roč. 24, 2014, č. 4, s. 441-444 [cit. 2015-08-02]. Dostupný z WWW: http://www.biomedres.info/yahoo site_admin/assets/docs/441-444-Kim-Cheolin.253134134.pdf.

26. Von Specht, M. H., Gardella, N., Ubeda, C., Grenon, S., Gutkind, G., Mollerach, M.: Community-associated methicillin-resistant Staphylococcus aureus skin and soft tissue infections in a pediatric hospital in Argentina. J. Infect. Dev. Ctries [online], roč. 8, 2014, č. 9, s. 1119-1128 [cit. 2015-08-01]. Dostupné z WWW: http://www.jidc.org/index.php/journal/article/view/4271.

MVDr. Alžbeta Kaiglová, PhD. Trnavská univerzita, FZaSP, LVMvZ Univerzitné námestie 1 91843 Trnava Slovensko e-mail: alzbeta.kaiglova@truni.sk 